\title{
Globalisation, the global labour movement and transnational solidarity campaigns: three case studies from Turkey
}

\begin{abstract}
Despite the hegemonic existence of transnational corporations, there are still certain ways to challenge their hegemony and highly un-democratic behaviour, particularly in connection with labour rights. The labour movement can still, to some extent, confront globalised monopoly capital, constituting a counter-force to that of capital in the context of neo-liberal globalisation. Various methods, policies and organisational bases exist for the labour movement to target specific TNCs, building coalitions with the victims and opponents of the system. Transnational solidarity campaigns are one of the most important tools used by organised labour to overcome the barriers to organise and to achieve basic demands from TNCs and their supply chains. This article draws lessons from three such successful campaigns in Turkish companies concerning the common characteristics which made determining contributions, while also pointing to the need for efforts to continue in the postcampaign environment to ensure that workplace gains and union branch organisation are sustainable.
\end{abstract}

Keywords: transnational corporations, globalisation, supply chains, union organisation, labour rights, labour movement, global unions, new working class, civil society, solidarity campaigns, union recognition, collective agreements

Introduction

Neo-liberal policies have provided fresh opportunities for monopolistic transnational corporations (TNCs) to construct a hierarchical supply chain to prompt their production in all parts of the globe. In this process of neo-liberal transition, international financial organisations, such as the International Monetary Fund (IMF) and the World Bank, have played major roles in guiding the world economy; the role of the state in the economy has been re-positioned; and the strength of organised labour has been challenged by direct - and mostly suppressive - control and interference by the state. This process, which is simultaneously taking place in most parts of the world, often in disregard of democratic procedures, has bolstered the forces of globalisation, often referred to as globalisation per se.

These developments have raised questions regarding the future of capital-labour relations. For developing countries, TNCs, with monopoly power in their respective sectors, have become the main sources of employment, technology and capital via foreign direct investment (FDI), through leading and maintaining large chains of production in many parts of the world. Together with the suppliers of TNCs, an over- 
whelming proportion of production has been concentrated within the control of TNCs, a process which has been facilitated by developments in information, communications and transportation technologies. These developments have led to substantial challenges to labour as regards organising, collective bargaining and the achievement of better working and living conditions.

In this paper, I argue that, despite such a hegemonic existence of TNCs, there are still certain ways of challenging their hegemony and highly undemocratic behaviour, particularly when it comes to labour rights. I assert that, despite its curtailed power, the labour movement is still, at least to a certain extent, able to confront globalised monopoly capital, constituting a countervailing force to that of capital in the context of neo-liberal globalisation. Various methods, policies and organisational bases may well provide suitable circumstances around which the labour movement may unite and target specific TNCs, in the process building coalitions with all the victims and opponents of the system. Transnational solidarity campaigns are one of the most important tools for organised labour to overcome the barriers to organise and to achieve basic demands from the TNCs and their supply chains.

This article is a part of a broader research study which was submitted and approved in January 2013 as an MA thesis to Sabanc1 University, Istanbul, titled Globalisation, the Global Labour Movement and Transnational Solidarity Campaigns: A Comparative Analysis of Three Solidarity Campaigns from Turkey. Apart from my academic studies, I am working as a Director of Organisation and International Relations in the Textile Workers Union, in which I am directly involved in the unionisation efforts of workers and in the co-ordination of transnational campaigns. My direct experience, together with my academic studies, provides me with the opportunity to focus more deeply on this issue.

In this article, I firstly analyse recent debates on the global labour movement and its role in the period of globalisation. Then, I focus on three solidarity campaigns from Turkey which have been successful in forcing TNCs and their suppliers to recognise a trade union after long, co-ordinated local picket struggles but organised on the basis of transnational campaigns. One part of the field work for the study constituted in-depth interviews with trade union officers of local and global unions and archival research in these trade unions, which forms an essential part of this analysis.

I examine three individual cases of such instances in Turkey in which organised labour has been able to force TNCs and their suppliers to accept labour's demands with respect to building better working and living conditions. These are: the UPS-Turkey campaign in 2010-2011 in Istanbul; the DESA campaign in 2008-2009 in Istanbul and Düzce; and the Novamed campaign in 2006-2006 in Antalya.

\section{Transnational corporations and the global labour movement}

An important component of the recent expansion of capitalism has been the growing strength of monopolistic TNCs due to the intense accumulation of capital and the continuous processes of monopolisation and financialisation of the capitalist economy (Erdoğdu, 2006: 39; Ar1, 2006: 24; Minqi, 2009: 103). Neo-liberal policies have been aimed at raising corporate profits via lowering wages and other social costs. Lean production and new methods of earning greater productivity and profit from employees 
have been introduced, and a global hierarchy of production through supply chains has been organised. However, neo-liberal policies have caused huge financial crises and economic recession. Private and public debt have broken historic records in national economies. Inequalities have deepened, unemployment rates have increased and national economies have collapsed through structural reforms and shock therapies. Furthermore, states have not provided welfare services as before. This has created a problem of legitimacy and has increased the level of opposition to such policies (Minqi, 2009: 105; Engel, 2011: 240-264).

TNCs do transmit capital, knowledge, ideas and value systems to developing countries. However, TNCs are profit-maximising corporations; they do not decide investment according to the local benefits that might arise. Through FDI, production and management may be centralised that could have a spill-over effect as regards local firms' intra- and inter-industry organisation; this may develop entrepreneurship in the host countries. FDI may pollute the natural environment, or it may also bring global standards to host countries. One of the main motivations of FDI in developing markets is cheap labour; this may lead to the greater exploitation of workers in some industries, such as the textiles sector, or it may increase general wages in some others, such as the automotive industry where wages are lower than in TNC home countries but higher than the general wage in host countries. Additionally, TNCs may benefit from a lack of proper labour and environmental legislation; however, they may introduce 'ethical' business practices such as 'corporate social responsibility' which may present opportunities for the local workforce to unionise and to raise their demands (Meyer, 2004: 259-261).

Therefore, TNCs and their direct investments may not bear the same or standard results. The local and national situation and class relationships would shape the direction of conflicts; while new challenges and opportunities may emerge for both labour and capital. Focusing on the 'class struggle' would provide us with information as to how these challenges and opportunities would be dealt with by labour and capital owners (Birelma, 2007: 6).

Beverly Silver (2009: 16-17) suggests that the flow of capital may cause a decrease in the organisational strength of workers in the one place but, at the same time, this may create and strengthen the working class in the new place. Therefore, she refutes the claim that unavoidable competition between workers causes a voluntary acceptance of slavery conditions. Additionally, such shifts in places of production are seen in some specific sectors, but not in all. The working class is an active participant in the political and economic spheres of life in all parts of the world. Globalisation and the strength of monopolistic TNCs may diminish the power of organised labour; however, by changes in its demands and strategies, the global labour movement is not only a victim or opponent of the ongoing process but, by its interventions, it may contribute to a re-production of the globalised economy via its social practices (Erdoğdu, 2006: 29).

\section{New internationalism}

The $21^{\text {st }}$ century suggests a wide range of opportunities in raising international solidarity, alongside developments in communications, information and transportation technologies. There have been serious critiques of the path of internationalism in the 
$20^{\text {th }}$ century as bureaucratic, hierarchical and nationally-focused, and there are alternative approaches to the ongoing efforts of internationalism as a more democratic, participative, activist, grassroots-based internationalism (Wills, 1998: 119). Sending solidarity letters is not sufficient; workers and pro-labour groups in various countries may not only meet, discuss and share experiences but also demonstrate, shout, fight and make demands together by gathering in certain cities to protest at 'summits', or by organising co-ordinated action days in various countries. There are also many methods of informing customers and the large mass of people via social media and TV, and publications. The emergence of a new working class movement also demonstrates that, in all parts of the world, the labour movement can find new methods of struggle.

The power of international monopoly capital and organisations, such as the IMF, the World Bank, the World Trade Organisation and the European Union, has homogenised the politics and economics of world states. Similar problems in different countries, and the same TNCs operating in tens of countries, provide the aspiration to branches of the labour movement to get in touch with each other at an international level. Anti-imperialist, anti-capitalist and anti-globalisation movements, and transnational networks of issue-related mass organisations, have flowered in all parts of the world. Consumer organisations, human rights organisations, feminist organisations and various other movements and organisations have established networks with each other at an international level and have been determined to come and act together to defend their common interests. For instance, consumer organisations may support the struggles of textiles workers by boycotting companies that violate the basic rights of workers. The feminist movement may support women workers protesting against their employers and demanding their rights. TNCs operating in different sectors may bring various trade unions to act together, or trade unions in different countries may decide to act together to target a specific TNC. Not just demonstrating solidarity but also joining forces together against the same policy or institution that has created the problems is understood to be very effective. Sharing experiences, learning from each other and acting together, against the IMF, the WTO or neo-liberal measures of governments, between the workers' movement, the human rights movement, the feminist movement, the peasant movement and the student movement, creates great synergy and has challenged mighty corporations, institutions and unchallengeable policies (Engel, 2001: 140).

Munck (2003: 27) stresses that the greatest strength of monopoly capital to expand its network to all parts of the world is also its weakness because, as capital expands, it becomes weaker as a result of the rising opposition of various segments of society. The ICFTU's 16 th Congress in 1996 stressed that the globalisation of the economy and changes in the type of production had increased the necessity of solidarity between workers. According to ICEM, national unions had, in the previous period, applied to global unions when they had failed to succeed at the national level; however, there is now the necessity to organise campaigns via combining national and transnational struggles together from the very beginning (Munck, 2003: 28-35). 


\section{Transnational solidarity campaigns: evidence from three sectors in Turkey}

This paper examines three transnational solidarity campaigns aimed at supporting the organising efforts of Turkish workers in companies in the supply chains of TNCs: namely, the UPS Turkey campaign (2010-2011) in the transportation sector; the DESA campaign (2008-2009) in the leather and textiles sector; and the Novamed campaign (2005-2006) in the chemicals sector.

This study argues that these campaigns might be able to overcome the legal barriers and the anti-union attitudes of employers by combining local struggles with transnational solidarity and with the power that comes from campaign efforts targeting brand image. These campaigns provide good case studies from which to understand the impact of transnational networks on the initiatives of local unions facing the severe challenges that they do in Turkey, given the suppressive legal and political milieu regarding labour rights. Workers have legal rights covering core labour issues, but the acts in force with regard to trade unions and collective bargaining procedures bring various obstacles to workers' attempts to unionise. Transnational solidarity campaigns could help trade unions overcome such challenges.

Act 2821 on Trade Unions and Act 2822 on the Collective Labour Agreement, Strike and Lock-Out were legislated by the military junta government following the 1980 coup d'état in order to suppress a labour movement which, prior to the coup, had become increasingly organised and militant. These acts remained in effect until November 2012; however, the newly-formulated Trade Unions and Collective Labour Relations Act is still a long way from ILO norms and continues the essence and logic of its predecessors (Özveri, 2012: 3; Birelma, 2007: 46).

The legal formulas enacted since the early 1980s have made organising, bargaining and striking almost impossible by means of the imposition of legal thresholds and various procedures which are used, in effect, to control and limit the power of the labour movement. Trade unions may be organised at industry-sector level and it is not permitted for trade unions to merge with unions from other sectors. The number of sectors is determined officially by the legislators. Also, the acts intervene in the internal affairs of trade unions in detail, and do not recognise the autonomy of trade unions. Even becoming a trade union member was a difficult process in Turkey, since workers could only become members on the condition of their registration by a public notary. To initiate collective bargaining, a trade union must overcome a $10 \%$ national sector 
threshold and a $50 \%+1$ workplace threshold. ${ }^{1}$ Even in the case where such thresholds are overcome, a company has the right of objection and it may apply to a labour court to check whether the union, even where it had received a certificate of competence from the Ministry of Labour and Social Security to represent the majority of employees, is valid or not. And court cases could take several years to conclude. Therefore, collective bargaining is an arduous process which usually takes a long time to be initiated (Birelma, 2007: 53).

Transnational solidarity campaigns are not just intended to overcome the legal barriers to unionisation. There are many methods of pressurising and harassing union members available to corporate managers. In most cases, when workers decide to unionise, they face dismissal and various types of oppression from management including bullying and harassment, forced resignations, threats and insults. In some of these instances, workers have organised picket lines outside plants to protest at employer actions with the aim of gathering public attention to convince an employer to accept negotiations with the union and to reinstate dismissed union members. Nonetheless, this remains another risky act as workers on a picket line could be arrested by the military or the police forces. Thus, transnational solidarity campaigns could apply public pressure on TNCs and their suppliers to stop discrimination and instances of bullying and harassment towards union members.

\section{The role of transnational companies in the success of local union campaigns}

Transnational capital's hegemony over its suppliers has begun to shape the policies of the global trade union federations. The Turkish labour movement has also begun to give more priority to transnational affairs and to solidarity campaigns. Thus, whenever these unions face legal and illegal thresholds, barriers and oppression as regards unionisation, they tend to apply to the European and global unions to which they are affiliated. They call for support from trade unions in the home countries of TNCs and from civil society movements that may target TNCs when they violate labour rights. Despite the adverse affects of the internationalisation of capital on local labour movements, the experiences of trade unions with respect to combining local struggles with cross-border

1 The $10 \%$ national threshold was in force in the case studies examined in this thesis. Under the new Trade Unions and Collective Labour Relations Act, the national threshold was, from December 2012, to be lowered to $3 \%$. A transition regime is in place such that, in the first two years, the threshold is $1 \%$, then for the next two it is $2 \%$ and finally, after 2018 , it will be $3 \%$. The AKP government highlighted this as a democratic improvement; however, it is important to note that the percentage of organised labour in Turkey in 2012 is $10 \%$ in general and almost $3 \%$ in the private sector, and that the $3 \%$ national threshold would not resolve the existing problems. Another point is that, by combining sectors and industries within which trade unions may act, the de facto threshold has actually increased. For instance, in the leather sector, there were 90000 registered workers in 2009 and so, with a threshold of $10 \%$, a trade union would need 9000 members. With the new Act, the leather and textiles sectors have been merged and the total number of workers has increased to 1000000 . A $3 \%$ threshold now means 30000 workers and, consequently, the threshold has increased to $30 \%$ for that trade union. Similar problems have occurred in many other sectors such as, for example, transportation (Özveri, 2012: $5)$. 
solidarity campaigns, via the targeting of TNCs and their suppliers, demonstrate that they can, indeed, overcome some of these barriers. To a certain extent, they can succeed in gaining recognition and initiating negotiations and bargaining processes to secure basic rights and improve working conditions. A local union, together with a global federation, may be able to take advantage of public pressure on TNCs to change their anti-union behaviour.

The three case studies in this paper demonstrate effective cross-border solidarity campaigns and they also encouraged several other unions from other sectors to mobilise for unionisation in TNCs and their supply chains. There are two phases in such struggles. The first phase is to be recognised by the corporation, to cease its anti-union attitudes and reinstate dismissed workers. Campaigns generally focus on the first phase. The main reason for this struggle is the creation of favourable conditions in which trade unions may act freely and workers unionise without fear. The second phase is to continue local efforts to overcome the legal thresholds in workplaces to start a collective bargaining process with a view to signing a collective agreement. The three cases in this paper were successful in achieving their basic 'phase 1' demands; but they have had different outcomes when post-campaigning 'phase 2' periods are analysed.

\section{The UPS campaign}

The UPS campaign is the most successful campaign within these three case studies: the UPS campaign was able not only to force the TNC to recognise labour rights in the first phase, but also then to push on to conclude the second phase. UPS is a global delivery company and the UPS Turkey solidarity campaign was successful in reinstating 163 dismissed union members while the local union (TÜMTIS) was able to sign a collective agreement after overcoming all the recognition thresholds in $2011 .^{2}$

TÜMTIS and ITF organised the campaign together and the European Transport Workers Federation (ETF) actively supported and was involved in the campaign. Even before recruiting members, ITF's Global Delivery Union Network and TÜMTISS had a joint meeting about the unionisation of UPS in 2008. TÜMTİS also had a political resolution approved by its $27^{\text {th }}$ General Assembly to organise in TNCs. ${ }^{3}$ Common policies could make things easier for the local and global unions to co-ordinate their campaign. 4

The transnational campaign was initiated as a result of the dismissal of union members in 2010 and the setting up of picket lines by TÜMTISS members. ${ }^{5}$ Picket lines of the 163 members brought a substantial financial burden to the local union. The ITF and its European organisation, the ETF, financially supported TÜMTIS and almost 100 thousand Euros were transferred to TÜMTISS to finance its picket lines. It is clear that,

2 ITF UPS campaign website http://www.itfglobal.org/campaigns/ups-justice.cfm [last accessed on 10 October 2012].

3 ibid.

4 Interview with Kenan Öztürk, President of TÜMTİS, Aksaray-Istanbul, 1 November 2012.

5 ITF UPS campaign website. 
without this financial support, TÜMTİS would not have been able to continue the picket line. ${ }^{6}$

TÜMTİS did not have a member of staff that was able to manage transnational relations. Therefore, the ITF employed two project managers experienced in the transnational movement to co-ordinate the campaign. These managers were able to struggle together with workers on the picket line, educate employees, carry out research on the company, report all developments to the international office with regard to the struggle and act as a bridge between the local union, the global federation and the American union. ITF co-ordinated the transnational campaign very closely on a dayto-day basis, and responsibility for the co-ordination of the campaign was taken by ITF Road Transport Section Secretary, Mac Urata. Additionally, the local union's determined struggle attracted sympathy from unions in all parts of the world that were able to transfer money and offer support, and organise actions. ${ }^{7}$

TÜMTİS also took a resolution to the ITF's 42nd General Assembly in Mexico in August 2010 in support of their struggle. This proposal was approved by the Assembly. However, Kenan Öztürk, President of the union, observes that TÜMTİS had to conduct a great effort to express their campaign and convince delegates. ${ }^{8}$ The result of the resolution was that the ITF called for an international day of action on 1 September 2010. In forty cities in many countries, ITF affiliates protested at UPS offices. ${ }^{9}$

TÜMTIS tried to convince the US-based International Brotherhood of Teamsters (IBT) to support it, since this organisation had a direct relationship with the UPS headquarters. This was a more difficult task since IBT had a suspicious attitude towards TÜMTIS as a small, militant union while it was also disturbed by the mobilisation of European trade unions, having the impression that the reason was that they were against American capital. IBT also opposed the resolution in the General Assembly in support of the proposal by TÜMTIS and the ITF for an international day of action. However, the result of continuing and detailed communications between TÜMTIS, ITF and IBT was that the latter decided to change its policy towards the campaign and support TÜMTISS. Indeed, rising pressure on UPS from the USA and from Europe was instrumental in forcing UPS to the bargaining table. ${ }^{10}$

After the well-orchestrated international campaign, UPS, together with ITF, ETF, IBT and TÜMTIS, signed a protocol on 24th January 2011 which saw the reinstatement of a majority of the dismissed members, with the rest taking severance pay, while TÜMTİS could, after a nine-month struggle, freely organise among employees. And a short time after the protocol, TÜMTIS was able to cross the legal threshold, gain the support of the majority of employees and start a collective bargaining process. This culminated in a securing of the basic rights of workers; and almost all the demands of the union had been met.

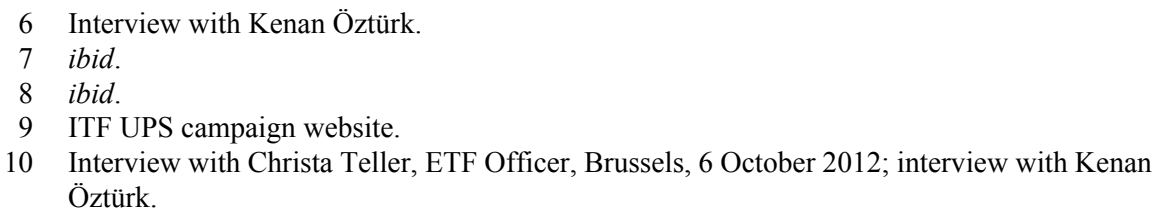

10 Interview with Christa Teller, ETF Officer, Brussels, 6 October 2012; interview with Kenan Öztürk. 


\section{The DESA campaign}

DESA is one of the leading leather companies in Turkey. It works as a supplier for many international brands such as Prada, Marks and Spencer (M\&S), El Cortes Ingles and Mulberry. The company has three plants: in Istanbul; Düzce; and Çorlu. Unionisation efforts at DESA began in April 2008 and the management's response was to dismiss forty members from the Düzce plant and one woman worker from the Istanbul plant. The 41 workers initiated a picket line in front of the two plants. Deri-İs and its global union, the International Textile, Garment and Leather Workers Union (ITGLWF) initiated a transnational campaign. Additionally, the struggle of Mrs. Aslan, alone outside the Istanbul plant, and the oppression towards her with various measures, including the kidnap of her daughter, attracted the attention of the feminist movement in Turkey as well as the Clean Clothes Campaign (CCC) at European level.

The joint campaign, with the local union, the global union and civil society movements in association, was successful in forcing TNCs (other than Prada) to withdraw their orders as a result of calling on DESA customers to apply their codes of conduct and audit their suppliers. This campaign forced the DESA management to negotiate with the local and the global union and, on 24 August 2009, the parties signed a protocol to recognise each other. DESA accepted the reinstatement of some of the dismissed members, with severance pay for the rest.

The ITGLWF was a relatively small global union with regard to its staff and resources. Its late General Secretary, Neil Kearney, actively followed and led the campaign from the beginning, together with its Turkish affiliate, Deri-İş. Kearney sent warning letters to DESA, came to Turkey many times over the issue, made press statements, visited workers on picket lines to provide encouragement and negotiated with the employer directly. ${ }^{11}$ ITGLWF preferred to collaborate with NGOs, especially with the CCC to overcome its lack of resources to initiate campaigns (Anner et al. 2006: 19).

Neil Kearney was a leading figure representing the global union as well as the officer in charge of co-ordinating the interaction between the global union, the local union and the CCC. Together with the CCC, ITGLWF not only targeted DESA, but also created pressure on DESA customers and both M\&S and El Cortes Ingles stopped ordering through DESA. Therefore, ITGLWF's policy in supporting its affiliate in its organising activities, through campaigns and aiming to work together with civil society organisations, and the local union's willingness to work with local solidarity platforms, particularly those organised by feminist organisations, saw to it that a broad-based coalition could successfully be formed.

Nevertheless, the ITGLWF was not able to mobilise its Italian affiliates. DESA's main customers were Marks and Spencer from the UK and Prada from Italy. M\&S stopped its orders as a consequence of the campaign, but Prada insisted on continuing to work with DESA; and was even able to take advantage of the campaign by decreasing the cost of its products. Deri-İş and ITGLWF called on the Italian unions to take this issue on their agendas and convince Prada to take a step back, but this did not occur.

11 Interview with Musa Servi - President of Deri-İş, Bostancı-Istanbul, 10 September 2012. 
According to Deri-İş, the Italian trade unions acted in a nationalist way, defending their country's brand instead of demonstrating labour solidarity. ${ }^{12}$

ITGLWF was not in a position to give material and financial support to its affiliate while, in addition, this was the first experience for Deri-İs in organising a transnational campaign. Furthermore, DESA is the largest company in its sector, with almost 2000 employees, almost equal to the union's total membership. ${ }^{13}$ TÜMTIS had been able to enjoy material support from its global union, the ITF, whereas Deri-İş had to spend its own sources on continuing the picket.

In the case of DESA, the union was able to form a coalition with issue-based civil society organisations both at national and transnational levels. At transnational level, the CCC became involved in the campaign and worked in a co-ordinated way with the ITGLWF. The participation of the CCC added activism to the campaign, while ITGLWF focused on more bureaucratic means, so that both complemented each other. At national level, a solidarity committee was formed by feminist organisations. This had particular sympathy for the struggle of Emine Aslan who was resisting alone outside the Istanbul plant. The solidarity committee organised actions and events together with the union and independently. The relationship was co-ordinated by an officer of the union who was also active in the feminist movement, which led them to formulate common policies more easily. ${ }^{14}$

The continuing relationship between the local union, the solidarity committee, the global union and CCC was maintained until DESA accepted negotiations on the signing of a protocol. Over the course of one year, various events were organised and public attention was earned. These campaigns also forced some TNCs to stop ordering with DESA given the fear that such a campaign might target them as well. Under the protocol, DESA confirmed that it would respect union rights and reinstate some union members, while Deri-İş and ITGLWF declared an end to the transnational campaign and informed DESA's previous customers of the agreement. Additionally, DESA as an employer, the ITGLWF's Neil Kearney and Musa Servi from Deri-İş organised joint employee meetings in DESA plants to inform them of the agreement. ${ }^{15}$

Over three years after the protocol, Deri-İş has not been able to reach a majority across the three plants. There may be many different organisational failures, but the main weakness of the transnational campaign was that the union did not gain the support of the Italian trade unions to force Prada to implement its code of conduct.

After the agreement, the level of confrontation in DESA did not stop; and there was no real peace. DESA management continued to put pressure on members and, witnessing their behaviour in the workplace, sought their resignation from the union. Deriİş adopted a defensive position, mostly trying to save its organisational power in Düzce and aiming to recruit members in the Istanbul plant, but called on international support

12 ibid.

13 ibid.

14 ibid.

15 Deri-İş (nd) 'Report on our activities in DESA', available at: http://xa.yimg.com/kq/groups/ 13224319/827893864/name/Report+on+our+activities+in+DESA.doc [last accessed on 10 September 2012]. 
when DESA intensified its pressure. The local union was able to sustain its organisational power in Düzce, having a de facto shop steward there, organising protest actions inside and outside the plant, asking for changes and improvements in the workplace with some of them being implemented; however, the union was not able to form a sustainable organisation in the Istanbul plant.

ITGLWF continued its support after the protocol in 2009 but it was not able to follow up the issue permanently because of changes in the leadership. Four sets of negotiations were held between the parties, ITGLWF sent a warning letter to DESA and the local union organised street actions in Turkey and in some other European countries to protest at the anti-union attitude of DESA, but there were little progress. In December 2012, however, the newly-founded IndustriALL global Union initiated a new transnational solidarity campaign against DESA. ${ }^{16}$

\section{The Novamed campaign}

One of the first attempts by a Turkish union to organise in free trade zones, where the right to organise had been legally banned at the outset of the establishment of the zones, was the Novamed campaign. The campaign was able to earn the support of the public as a consequence of the co-ordinated activities of the local and the global unions, together with the German union and feminist organisations, and was able to pass phase 1 by forcing the TNC to sign a collective agreement. However, it was not successful in gaining the support of a majority of the workers and it has not been able to re-sign the collective agreement. ${ }^{17}$

Novamed is a German company producing medicines in the Antalya free trade zone. It is affiliated with a German monopoly, Fresenius Medical Care. Most of the company's workforce is female. Petrol-İş (the Petroleum and Chemical Workers Union) started its activities in March 2005 and the majority of workers had been recruited by April 2006. The employer learned of the unionisation on 19 April 2006 and tried to get rid of the union. However, at that point, the union had passed the legal threshold and had gained its certificate of competence from the Ministry of Labour and Social Security with which it sought the initiation of collective bargaining.

The reaction of the employer was, on the one hand, to force members to resign while, at the same time, it employed sixty more workers so as to decrease the percentage of union members in the total workforce to less than $50 \%$. The union had a legal certificate, so the parties started to negotiate, but the employer refused to reach an agreement. Management thought that Petrol-İş had the support of only a minority of employees and so the corporation tried to force the union to initiate strike action, a failure of which would destroy the union's prestige and its organisational strength. ${ }^{18}$ According to the law, collective bargaining has a time limit at the end of which a strike must be declared, with employees then called on to vote to decide whether there would be a strike or not. Interestingly, the employer called on non-members to vote in favour

16 ibid.

17 Interview with Gün Bulut, Officer for Foreign Affairs, Altunizade İstanbul, 4 September 2012.

18 ibid. 
of a strike, while the union called on its members to vote against. When a majority voted for a strike, the union had to initiate strike action by its members.

Petrol-İş initiated the strike on 26 September 2006 with 84 workers, 82 of whom were women, with the strike consequently being known by the public as a women's strike. Petrol-İs decided to initiate a transnational campaign to find a solution to the unpromising situation in which it found itself. The International Federation of Chemical, Energy, Mine and General Workers' Unions (ICEM) and its German affiliate, IGBCE, actively supported the women's strike. Additionally, civil society organisations, especially among feminist organisations, formed solidarity committees. International delegations visited the strike and international public awareness was attracted.

The consequence of this campaign activity was that Novamed management accepted negotiations with the unions, including representatives of ICEM, the European Mine, Chemical and Energy Workers federation (EMCEF) and IGBCE, in September 2007 and, on 18 December 2007, the parties signed a collective agreement. By 2 January 2008, all employees on strike had gone back to work. ${ }^{19}$

ICEM's official policy on organising TNC supply chains had a positive impact on the decision of ICEM and EMCEF to support the Novamed strike. The ICEM Executive Committee had a meeting on supporting the Novamed workers, accepting a resolution on the Novamed strike on 10 May 2007 and calling for transnational solidarity. ICEM also called for days of action to support the striking workers. For instance, in ICEM's statement of 7 March 2007, an urgent global day of action was called by ICEM General Secretary, Manfred Warda, to show solidarity on 8 March, International Women's Day. Women's committees of many unions from various countries and from European and global unions also sent solidarity messages to Petrol-İş. ${ }^{20}$ International envoys and the sending of solidarity messages are effective not only in giving moral support to workers but also these messages and visits spread information to various countries and damage the image of the brand. ${ }^{21}$

The German trade union, IGBCE, actively supported Petrol-İs in the struggle. IG$\mathrm{BCE}$ is a strong trade union and has a level of influence on the leadership of ICEM. Therefore, from the beginning, it was easier for ICEM and IGBCE to co-operate and co-ordinate the campaign. IGBCE also has close relations with Petrol-İş, and this made it easier for the German and Turkish trade unions to work together. ${ }^{22}$

It was the international days of action beginning on 8 March that forced the German company to start negotiations and, without the transnational solidarity and public pressure, it would not have been possible to organise the strike. ${ }^{23}$ Petrol-İş, ICEM, EMCEF and IGBCE were able to co-ordinate the transnational campaign by putting pressure on the headquarters in Germany and, hence, a collective agreement could be signed. However, the union was not able to resolve the levels of polarisation in the workplace

19 Interview with Gün Bulut.

20 Petrol-İș website (nd) Novamed Dosyası http://petrol-is.org.tr/etiket/novamed [last accessed on 3 September 2012].

21 ibid.

22 Interview with Gün Bulut.

23 ibid. 
and, despite the success of the strike, it was not able to persuade other workers to join the union. Three years later, when the period of the collective agreement ended, the union was not able to re-sign it. $^{24}$

The Novamed campaign was one of the pioneering campaigns on which trade unions and issue-based civil society organisations were able to collaborate over a long period to achieve victory for a particular labour struggle. The Novamed strike was known as a strike of women workers, with the women deciding to unionise to counter the company's ongoing pressure and discrimination based generally on gender issues. For instance, workers had to consult management, and ask for permission, before getting pregnant. These instances attracted the attention of feminist organisations and many solidarity committees were formed to support the Novamed strike in Istanbul, Ankara, Izmir and Adana. They undertook spontaneous actions and also visited the striking workers in Antalya. ${ }^{25}$

The involvement of feminist organisations also spread information about the strike to the general public. Large numbers of people were informed and the German company was exposed. The co-ordinated campaign between the solidarity committees and the union was led by a well-known feminist author and activist who is responsible for the publication of the Petrol-İş women's magazine. ${ }^{26}$ This also eased the path for feminist organisations to engage in a campaign with a trade union which sought to combine together labour and gender issues.

In the case of DESA, the involvement of the global and European unions did not extend to the lower apparatus of these organisations. However, in the Novamed case, women trade unionists actively supported the campaign. ${ }^{27}$

\section{Evaluation of the case studies}

Analysing the three case studies included in this article, it is clear that there are some common characteristics, having a critical effect on the successes and failures of the individual campaigns, which prevail. First of all, the organisational strength, motivation and mobilisation of workers at local workplace level are of crucial importance to the success of campaigns. The fate of a campaign is determined by the organisational strength and capacity of local workers, and the local union, to continue with it.

Transnational solidarity is of secondary importance, but complements the local struggle to achieve success by removing some of the barriers facing the organisational efforts of employees. Furthermore, a transnational campaign on TNCs and suppliers, via the mounting of public pressure, may be able to influence corporations to change their behaviour. Phase 1 may be completed as a result of the common efforts of struggle

\footnotetext{
24 ibid.

25 ibid.

26 Petrol-İş is the only union in the Turkish labour movement which publishes a regular women's magazine. Other unions generally focus on women's issues as part of their regular magazines, but Petrol-İş has a distinctive character in its relations with gender policy. The presence of a full-time officer for this issue means that the union may sustain regular education activities on gender issues and continue publications on these issues.

27 Interview with Gün Bulut.
} 
in the workplace and transnational support. When phase 2 is started, however, the crucial role is on workers to prepare the conditions to start bargaining process.

Another condition for the success of the transnational involvement in campaigns is the presence of common policies and interests between the global federations and the local union. There may be other organisations involved in a campaign coalition, but the two main pillars of a campaign are the local union and the global federation and key to its success are their efforts to co-operate on it as well as to co-ordinate it. These three cases saw the support of the global federations being forthcoming as a consequence of policies to organise TNCs and their suppliers. Such policies encourage local unions to mobilise their forces to unionise TNCs and their supply chains.

The support of TNC home-country trade unions also has crucial importance to the fate of campaigns. Such unions generally own the strongest presence within the corporation and they could have direct relations with the management of the TNC at headquarters level. They could, in principle, deal with TNCs and convince them to take positive actions towards respecting labour rights.

The involvement of civil society organisations brings dynamism, activism and militancy to campaigns. Their activities could attract the attention of the public and the media much more easily and would be a source of extra pressure on TNCs. The common interests of NGOs and trade unions should be clearly defined. However, trade unionNGO relations also present complicated issues. Both parties should have similar concerns, goals and policies if they are to co-ordinate their associated activities, and trade unions and NGOs need to speak the same language if they are to see their activities right through to the end. Any possible break in the coalition before the end of the campaign would bring an extra disadvantage as regards its fate.

In all these cases, co-ordinators performed the most important duties in the campaigns. Co-ordinators worked for trade unions as full-time officers, followed the local struggle very closely and reported all activities and violations of labour rights on a daily basis by providing concrete evidence that could be spread rapidly via the coalition to the general public. They could also talk the same language as all the parties in the coalition. Their role in translating the interests and motivations of each party in the coalition to each other, as well as their co-ordination and guidance activities, is of crucial importance.

Actions and demonstrations are one of the most important elements in transnational solidarity campaigns. Sending solidarity letters to workers and writing warning letters to the corporation could have a partial effect in campaigns; however, the main and most effective tool is the organising of visible actions and demonstrations.

At a local level, the organising of such activities is easier, more frequent and more necessary. Earning the support of local people and creating daily pressure on a corporation are necessary to achieve workers' demands. Picketing and striking also represent daily actions of workers, but national and international days of action are important components of campaigns. Spreading activities and demonstrations to other cities and countries might shame corporations and force them to reach an agreement with workers. After the initiation of such a transnational campaign, campaigners should deliver a clear message to TNCs that the dispute could not be kept at a local level and that it could be converted into an international dispute, exposing the corporation at a global level. The 
main aim of global unions' calls for international days of action is to force the TNC headquarters to involve them in solutions to the local dispute. When one of these international days of action concludes, according to the reaction of TNCs, the preparation of other action days could be initiated.

When a campaign has been concluded by achieving the basic demands of workers, participants in the coalition should follow up on the processes in the post-campaigning period. TNCs and their suppliers may accept the demands of labour as a result of the joint activities and joint strength of the local and global unions alongside civil society organisations. Therefore, in the post-campaigning period, this pressure should be continued to reach the second, and the more important, goal - which is to maintain a sustainable union organisation in workplaces bound by a collective agreement.

\section{Interviews}

Christa Teller, ETF Officer, Brussels, 6 October 2012. 2012.

Gün Bulut, Officer for Foreign Affairs, Petrol-İş, Altunizade İstanbul, 4 September

Kenan Öztürk, President of TÜMTIS, Aksaray-Istanbul, 1 November 2012.

Musa Servi, President of Deri-İş, Bostanc1-Istanbul, 10 September 2012.

\section{References}

Anner, M, I. Greer, M. Hauptmeier, N. Lillie and N. Winchester (2006) 'The Industrial Determinants of Transnational Solidarity: Global Interunion Politics in Three Sectors' European Journal of Industrial Relations 12(1): 7-27.

Arı, F. A (2006) 'Küreselleşme ve kuralsizlaştirma' Çalışma ve Toplum 3, İstanbul: Birleşik Metal İş Sendikası Yayınları.

Birelma, A (2007) Three cases of worker mobilization in contemporary Turkey unpublished MA thesis, Boğaziçi Üniversitesi.

Deri-İş (nd) 'Report on our activities in DESA' http://xa.yimg.com/kq/groups/ 13224319/827893864/name/Report+on+our+activities+in+DESA.doc [last accessed on 10 September 2012].

Engel, S (2001) Işşi Hareketi Iç̧inde Düşüne Tarzı İçin Mücadele Verlag Neuer Weg Yayınları, Türkçe baskı.

Engel, S (2011) Küreselleşme: tanrıların günbatımı, uluslararası üretimin yeniden örgütlenmesi İstanbul: Umut Yayımc1lık.

Erdoğdu, S (2006) Küreselleşme sürecinde uluslararası sendikacılık Ankara: İmge Kitabevi.

ICFTU (2004) A trade union guide to globalisation (2nd Edition).

ITF UPS campaign website http://www.itfglobal.org/campaigns/ups-justice.cfm, [last accessed on 10 October 2012].

Özveri, M (2012) Toplu İş İlişkileri Yasa Tasarısı ve Sendikal Haklar İstanbul: Birleşik Metal İş Yayınları. 
Meyer, K. E (2004) 'Perspectives on Multinational Enterprises in Emerging Economies' Journal of International Business Studies 35(4): 259-276. Palgrave Macmillan Journals http://www.jstor.org/stable/3875130 [last accessed on 26 October 2011].

McGrath, E. M and D. Ş. Dinler (2011) 'Strategic Campaigning in Multinational Companies: The Case of United Parcel Service (UPS) in Turkey' Juridicum 3.

Minqi, L (2009) Yükselen Çin ve Kapitalist Dünya Ekonomisinin Çöküşü İstanbul: Epos Yayınları.

Munck, R (2003) Emeğin Yeni Dünyası Küresel Mücadele Küresel Dayanışma İstanbul: Kitap Yayınevi.

Petrol-İş website (nd) Novamed Dosyası http://petrol-is.org.tr/etiket/novamed [last accessed on 3 September 2012].

Silver, B (2009) Emeğin Gücü, 1870’den Günümüze İşçi Hareketleri ve Küreselleşme İstanbul: Yordam Kitap.

Wills, J (1998) 'Taking on the CosmoCorps? Experiments in Transnational Labor Organization' Economic Geography 74(2): 111-130. http://www.jstor.org/stable/ 144278 [last accessed on 26 October 2011]. 